TAX EXEMPTIONS FOR

\section{RELIGIOUS ORGANIZATIONS:}

\section{THE UNITED STATES,}

\section{THE EUROPEAN UNION,}

\section{AND TURKEY}

\author{
Ayşe Nil TOSUN \\ Assoc.Prof.Dr., HacettepeUniversity \\ Faculty of Economics and Administrative \\ Sciences \\ Department of Public Finance \\ nilt@hacettepe.edu.tr
}

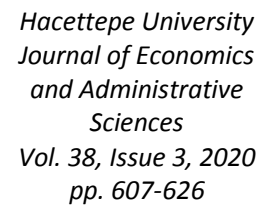

bstract: Many countries grant tax
exemptions to religious organizations.
The legitimacy of these exemptions
hinges on nationally and
internationally protected freedoms of thought, conscience, and worship. Thus, it is important that religious organizations comply with international tax rules and exemptions. This study aims to compare religious tax exemptions in the United States (US) and the European Union (EU) with those of Turkey, reveal basic differences in religious-based tax exemptions and evaluate tax exemptions for religious organizations in general. Religious tax exemptions are compared by evaluating relevant laws, tax policies, court and commission decisions. As seen in this study, no consensus has been reached yet regarding tax policy for religious organizations. This study's findings revealed significant disparities in religious-based tax policies between the United States, the European Union and Turkey. To avoid problems, national and international laws should be enacted to eliminate this conflict. Tax regulations must comply with laws that protect freedom of thought, conscience and religion. Otherwise these persistent differences in tax policy are likely to have substantial historical, cultural, and political effects.

Keywords: Tax law, tax exemptions, freedom of religion; European Court of Human Rights, comparative study. 


\section{DİNI ORGANIZASYONLAR}

\section{İÇIN VERGİ MUAFIYETLERİ:}

\section{AMERÍKA BİRLEŞIK DEVLETLERİ,}

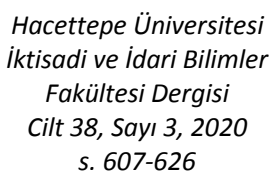

Hacettepe Üniversitesi iktisadi ve Idari Bilimler Fakültesi Dergisi

Cilt 38, Sayı 3, 2020

s. $607-626$

\section{AVRUPA BİRLİĞİ VE TÜRKIYYE}

\author{
Ayşe Nil TOSUN \\ Doç.Dr., Hacettepe Üniversitesi \\ İktisadi ve İdari Bilimler Fakültesi \\ Maliye Bölümü \\ nilt@ hacettepe.edu.tr
}

z: Birçok ülke dini organizasyonlara
vergi muafiyetleri tanımaktadır. Bu
muafiyetlerin meşruluğu ulusal ve
uluslararası olarak korunan düşünce,
vicdan ve din özgürlüğüne dayanmaktadır. Bu sebeple dini organizasyonların uluslararası vergi kuralları ve muafiyetleri ile uyumlu olması önemlidir. $\mathrm{Bu}$ çalışma, Amerika Birleşik Devletleri'nde (ABD) ve Avrupa Birliği'ndeki (AB) dini vergi muafiyetlerini Türkiye' dekiler ile karşılaştırmayı, din tabanlı vergi muafiyetlerindeki temel farklılıkları ortaya çıkarmayı ve genel olarak dini organizasyonlar için olan vergi muafiyetlerini değerlendirmeyi amaçlamaktadır. Dini vergi muafiyetleri, ilgili kanunlar, vergi politikaları mahkeme ve komisyon kararları değerlendirilerek karşılaştırılmıştır. Bu çalışmada görüldüğü üzere dini organizasyonlara karş1 vergi politikalarında henüz bir fikir birliğine varılmamıştır. $\mathrm{Bu}$ çalışmanın bulguları Türkiye, Avrupa Birliği ve Amerika Birleşik Devletleri arasında din tabanlı vergi politikalarında belirgin farklılıklar ortaya çıkarmıştır. Problemlerden kaçınmak için ulusal ve uluslararası yasalar bu çatışmayı ortadan kaldıracak şekilde çıkarılmalıdır. Vergi regülasyonları düşünce, vicdan ve din özgürlüğünü koruyan yasalar ile uyumlu olmalıdır. Aksi takdirde vergi politikasındaki bu 1srarc1 farklılıkların politik, kültürel ve tarihsel etkileri olması muhtemeldir.

Anahtar Sözcükler: Vergi hukuku, vergi muafiyetleri, din özgürlüğü, Avrupa İnsan Hakları Mahkemesi, karşılaştırmalı çalışma. 
Tax Exemptions for Religious Organizations: The United States, the European Union...| TOSUN

\section{INTRODUCTION}

Houses of worship and religious organizations have received tax exemptions since ancient times. Especially in democratic states, governments often exempt these institutions from inheritance, gift, and sales taxes and allow parishioners to deduct their donations from income or corporate taxes. The legitimacy of these exemptions remains a topic of debate among scholars and policy makers. Advocates argue that these exemptions help separate the state from religious institutions and that they serve the public interest because houses of worship and religious organizations meet societal needs (e.g., helping the poor and promoting moral behavior, healthy lifestyles, and honesty). In this aspect, exemptions promote values that benefit society (Martin, 2017; Shertreet, 2007). However, opponents argue that exemptions encourage state participation in and subsidization of religious institutions. Moreover, some governmentsubsidized organizations can obtain sufficient donations on their own, making tax exemptions unnecessary (McCormack, 2011; Roemhildt, 2003; Whitehead, 1991; Yalti, 2013).

Underpinning these tax exemptions are the rights to freedom of thought, conscience, and religion, which are legally protected in many countries and by international conventions such as the European Convention on Human Rights (ECHR). Countries can implement policies that reflect specific consideration of their constituents' needs and the public interest, but increasing globalization requires that these policies comply with international law. Indeed, several lawsuits have been filed around the world in national and international courts to challenge these exemptions. These cases cite violations of freedom of thought, conscience, association, and religion; prohibition of religious worship; and discrimination against houses of worship. Religious organizations may be especially targeted for lawsuits because in many countries they also serve as nongovernmental foundations and associations with fundraising and income that are managed under civil legal entities. The very high revenues of these organizations often attract attention from tax authorities. Moreover, these organizations frequently interfere with domestic corruption scandals, though such activity is beyond the scope of this study.

Taxation of houses of worship and religious institutions is a particularly sensitive topic in regions with diverse religious populations, such as the United States (US) and the European Union (EU). Although Turkey has a Muslim majority, it is home to many Islamic sects (e.g., Alawism and Sunnism), as well as Christians, Jews, Jehovah's Witnesses, and Mormons. Turkey began its accession to the EU in 1963 with the Ankara Agreement (also known as the Association Agreement). After becoming a candidate member in 1999, Turkey began full membership negotiations in 2005 and has since worked to adapt to the EU community acquis. Turkey is a signatory to the ECHR, 
under which Turkish citizens can file individual applications to the European Court of Human Rights. It is therefore important that Turkey implement policies that align with international laws, including those concerning tax exemptions granted to houses of worship.

This study aims to compare religious tax exemptions and religious freedom laws in the US and the EU with those of Turkey, assess Turkish tax policy toward religious organizations, and make policy recommendations for Turkey. To do so, religious freedoms and tax exemptions were investigated in these regions, along with income, corporate, real estate, value added, and sales taxes. By evaluating relevant laws, court documents, and commission decisions and judgments, the study revealed important differences in religious-based tax exemptions in the US, the EU, and Turkey.

Additionally, examination of a large volume of literature demonstrated that no prior studies on this issue had been published. Thus, this study also aims to fill this existing research gap.

\section{RELIGIOUS FREEDOMS AND TAX EXEMPTIONS IN THE UNITED STATES, THE EUROPEAN UNION, AND TURKEY}

This section addresses some general rules related to religious freedoms and tax exemptions in the US, the EU, and Turkey.

\subsection{United States}

Examining the general rules regarding religious freedoms and tax exemptions in the US requires some understanding of the U.S. Constitution, which separates the church and the state. The First Amendment of the U.S. Constitution states,

Congress shall make no law respecting an establishment of religion, or prohibiting the free exercise thereof; or abridging the freedom of speech, or of the press; or the right of the people peaceably to assemble, and to petition the Government for a redress of grievances.

Religious organizations in the US may be required to pay taxes at both federal and state levels. At the federal level, religious organizations are generally exempt from many taxes under Section 501 of the US Internal Revenue Code. Individual states also grant tax exemptions, although an organization that is exempt at the federal level may not be exempt at the state level. Section 501(c)(3) of the US Internal Revenue Code lists the following criteria for tax exemption: 
Corporations and any community chest, fund, or foundation, organized and operated exclusively for religious, charitable, scientific, testing for public safety, literary, or educational purposes, or to foster national or international amateur sports competition (but only if no part of its activities involve the provision of athletic facilities or equipment), or for the prevention of cruelty to children or animals $[\ldots]$

Although religious organizations qualify for substantial tax exemptions under Section 501, they may lose their status if they create propaganda, influence legislation, participate in political campaigns, or violate fundamental public policies (Crimm, Winer 2013; Vaughn 2004). Some studies suggest that racist or anti-same-sex marriage views may disqualify churches from tax exemptions (Brunson, Herzig 2017). For example, in 1983, the nonprofit religious and educational institution, Bob Jones University, lost a lawsuit with the Internal Revenue Service after losing its tax-exempt status due to racist practices that conflicted with federal policies (Brunson, Herzig 2017).

\subsection{European Union}

After the Second World War, the Council of Europe was founded to build reconciliation and mutual trust among people in Europe through establishing common institutions, standards, and conventions. Of the 47 Council of Europe member states, 28 are members of the EU. All Council of Europe member states belong to the ECHR, which was drafted to protect human rights, democratic values, and the rule of law.

Article 9 of the ECHR protects freedom of thought, conscience, and religion. It states,

Everyone has the right to freedom of thought, conscience and religion; this right includes freedom to change his religion or belief and freedom, either alone or in community with others and in public or private, to manifest his religion or belief, in worship, teaching, practice and observance. Freedom to manifest one's religion or beliefs shall be subject only to such limitations as are prescribed by law and are necessary in a democratic society in the interests of public safety, for the protection of public order, health or morals, or for the protection of the rights and freedoms of others.

The ECHR does not limit religious beliefs. However, it recognizes that in diverse and democratic societies, limitations may be required to reconcile interests among various groups. The European Court of Human Rights acknowledges that religious organizations in many countries operate as associations. As such, the Court considers both Article 9 of the ECHR, which protects the freedom of conscience and religion, and 
Article 11, which protects freedom of assembly and association, in decisions concerning religious practice and tax exemptions.

According to Article 11 of the ECHR,

Everyone has the right to freedom of peaceful assembly and to freedom of association with others, including the right to form and to join trade unions for the protection of his interests ... No restrictions shall be placed on the exercise of these rights other than such as are prescribed by law and are necessary in a democratic society in the interest of national security or public safety, for the prevention of disorder or crime, for the protection of health or morals or for the protection of the rights and freedoms of others. This article shall not prevent the imposition of lawful restrictions on the exercise of these rights by members of the armed forces, of the police or of the administration of the State.

Different countries may classify religious institutions as associations or houses of worship, which can be problematic when the Court intervenes to address disparities in treatment among these organizations. Sometimes, the government allows exemptions for religious entities that are defined as houses of worship. At other times, however, it prohibits exemptions for entities defined as associations (e.g., religious sects and new religious movements). These inconsistencies can lead to conflict when both current case law of the European Court of Human Rights and the ECHR grant religious groups and their individual members equal protection under the law (Council of Europe Research Divisions, 2011). Thus, the Court also considers Article 14:

The enjoyment of the rights and freedoms set forth in this Convention shall be secured without discrimination on any ground such as sex, race, colour, language, religion, political or other opinion, national or social origin, association with a national minority, property, birth or other status.

\subsection{Turkey}

The Constitution of the Republic of Turkey establishes Turkey's government, including its guiding principles, rules of conduct, and responsibilities to citizens. Article 24 of the Constitution protects freedom of thought, conscience, and religion:

Everyone has the right to freedom of conscience, religious belief and conviction. Acts of worship, religious services, and ceremonies shall be conducted freely, provided that they do not violate the provisions of Article 14. No one shall be compelled to worship, or to participate in religious 
Tax Exemptions for Religious Organizations: The United States, the European Union...| TOSUN

ceremonies and rites, to reveal religious beliefs and convictions, or be blamed or accused because of his religious beliefs and convictions ...

Although Turkish tax law grants many tax exemptions to houses of worship and religious organizations, the European Commission criticized the low number of nonprofit organizations that benefit from these exemptions in its 2014 Progress Report of Turkey (European Commission, 2014).

\section{INCOME AND CORPORATE TAX IN THE UNITED STATES, THE EUROPEAN UNION, AND TURKEY}

The comprehensive definition of income tax includes both personal and corporate incomes. Since most houses of worship and religious institutions are nonprofit organizations, many countries do not consider them to be income tax payers. However, to fulfill their goals and purposes, these organizations often participate in activities such as selling books and organizing concerts that generate revenue. In these scenarios, they may be required to pay income or corporate tax.

\subsection{United States}

Section 501 of the US Internal Revenue Code exempts many organizations, including religious institutions, from federal income tax if they meet certain requirements. Taxpayers' donations to these organizations can also be deducted from their personal income tax. However, tax-exempt organizations may have to pay unrelated business income taxes if they engage in revenue-generating activities. These taxes are complicated, though, because it can be difficult to determine which activities are exempt. Section 501 defines activities in terms of unfair competition against the private sector. Particularly, if a private-sector organization performs a specific activity that generates a profit, then income generated by a tax-exempt religious institution performing that same activity is taxable (Fricke, 2016).

\subsection{European Union}

In some EU countries, such as Germany, Italy, and Denmark, churches act as tax collectors, not taxpayers, because they collect taxes (i.e., church tax) from their communities. Church taxes usually include a proportion of income tax (Berghammer $v d ., 2018)$. Similar to the US and Turkey, religious organizations in many EU countries operate as nonprofits and thus are exempt from income and corporate taxation. Also similar to EU and Turkish law, revenue generated by these organizations is taxable (corporate or income) if it comes from commercial activity (Anheier, Seibel, 1993; Archambault, 1997; Barbetta, 1999). Due to historical, religious, and cultural differences across member states of the EU, tax policies regarding donations to religious 
organizations vary. Unlike in the US, where such donations can be deducted from income tax, many EU countries impose an upper limit on charitable contribution deductions. For example, in Germany, taxpayers can deduct up to $20 \%$ of their pre-tax income as donations to non-profit organizations that are recognized by the tax office. In the Netherlands, the tax benefit on donations is capped at $10 \%$ of the annual taxable income (Centre d'Étude et de Recherche sur la Philanthrophie, 2015; European Fundraising Association, 2018; Faulhaber, 2014).

\subsection{Turkey}

In Turkey, many religious institutions are organized as nonprofit organizations that are exempt from income or corporate taxation. However, revenue from their commercial enterprises (e.g., selling religious books or educational courses) is subject to income or corporate taxes.

Turkey often changes its tax policies regarding deductions for religious donations. From 1985 to 1998 , Law No. 3239 stipulated that all expenses related to mosque construction and assistance were tax-deductible. In 1998, Law No. 4369 abolished this broad tax deduction, limiting such deductions. Law No. 6322 in 2012 expanded the legislation to include all donations to all houses of worship. Specifically, Article 10/1/ç of the Corporate Tax Law and Article 89/5 of the Income Tax Law allow deductions for

all expenditures made due to the construction of [...] houses of worship [...] and the construction of facilities providing religious education under the supervision of the Directorate of Religious Affairs

and provide that

all kinds of donations and charities granted to these organizations for the construction of these facilities, and all kinds of cash and in-kind donations and charities granted to enable the existing facilities to continue their activities can be deducted from profit in the corporate tax base.

Article 10/1/c of the Corporate Tax Law and Article 89/4 of the Income Tax Law allow limited deductions for donations granted to associations and foundations that offer public benefit. 
Tax Exemptions for Religious Organizations: The United States, the European Union...| TOSUN

\subsection{Comparing Income and Corporate Tax Policy in Turkey with Policies in the United States and the European Union}

The US, the EU, and Turkey levy income or corporate tax on the commercial activities of religious organizations if those activities create unfair competition in the private sector. Many EU member countries levy a church tax, which is an income tax that religious organizations collect from their members. There is no such practice in Turkey, and the First Amendment of the US Constitution explicitly prohibits such a tax.

In the US, religious organizations are exempt from income tax, and individual donations to these institutions can be deducted from the income tax. To keep their exempt status, organizations must refrain from creating propaganda or violating public policy. Even with these requirements, the US offers comprehensive tax exemptions to religious organizations, although its limits and conditions are stricter than those in Turkey and many EU countries. Turkey generally supports religious organizations and does not prevent them from intervening in politics or violating policy. In Turkey, all donations toward the building and maintenance of houses of worship and religious schools are tax-deductible. However, Turkey allows only a small portion of donations to nonprofit organizations that offer public benefit to be deducted from the donor's income tax. In the US, such donations are fully deductible from income taxes. Practices in EU countries vary. In Turkey, unlike the US and many EU countries, worship is not broadly defined, which makes charitable contribution deductions difficult since they may be deductible only if they are made to a particular religion or sect.

\section{PROPERTY TAXES IN THE UNITED STATES, THE EUROPEAN UNION, AND TURKEY}

Property owners pay taxes on the land and buildings they own, and these taxes can be significant sources of income for municipalities. Religious organizations in the US, the EU, and Turkey often own numerous properties, including houses of worship, land, cemeteries, schools, hospitals, elder care homes, shelters for the poor and homeless, and orphanages. Thus, property tax exemptions for these organizations often comprise large holdings. The legitimacy of these property tax exemptions is a common issue of debate and judicial discussion (Brown, Mahon 1959; Fisher, 2002). Lawsuits have challenged whether these exemptions protect freedom of thought, conscience, and religion. The resulting court decisions often involve careful consideration of discrimination, preferential treatment, and special conditions.

\subsection{United States}

US property taxes are important sources of revenue for many local governments, each of which may have different tax procedures. Religious exemptions are subject to 
TOSUN | Dini Organizasyonlar İçin Vergi Muafiyetleri:Amerika Birleşik Devletleri, Avrupa Birliği...

debate and judicial proceedings. For example, in the 1970 case Walz v. Tax Commission of the City of New York, a real estate owner sued the New York City Tax Commission for property tax exemptions granted to religious organizations. The plaintiff claimed that the exemptions represented a subsidy that indirectly forced him to contribute to those churches. As such, they violated the US Constitution and its guarantee of freedom of thought, conscience, and religion. The US Supreme Court ruled that the exemption did not violate the First Amendment, stating that complete and perfect separation between houses of worship and the state would be impossible and that the aim of the constitutional amendment instead was to prevent excessive intervention. It found that property tax exemptions implied a benevolent neutrality toward churches and religions that neither promoted nor punished a particular religion, church, or group (Howard, 1971; Walz v. Tax Commission of the City of New York, 1970). This decision settled the question regarding the constitutionality of property tax exemptions for houses of worship and religious organizations.

Sometimes, the courts must decide whether religious organizations deserve property tax exemptions. For example, in Golden Writ of God v. Dept. of Rev. (1986), the Supreme Court of Oregon decided that a religious group known as the Golden Writ of God was ineligible for a property tax exemption for 230 acres of agricultural land that was not used exclusively for religious and charitable purposes (Fisher, 2002).

\subsection{European Union}

In the EU, definitions of property tax, eligibility for property tax exemptions, and whether these taxes are collected at the local or state level vary from country to country. Generally, lands and properties used for religious purposes are exempt, though the issue has been challenged in court. In the 1992 case Salvador \& Moratilla v. Spain, the Protestant Church of Spain claimed that the Catholic Church received an unfair tax exemption that violated Article 9 of the ECHR. The European Court of Human Rights ruled that Article 9 does not exempt all houses of worship from all forms of taxation. The Court found that the different treatment (i.e., property tax exemption) was legal because it was based on a contract between Spain and the Vatican. Thus, they found no violation of Article 1 or Article 9 (Iglesia Bautista El Salvador \& José Aquilino Ortega Moratilla v. Spain 1992)

In the controversial 2014 case, Church of Jesus Christ of Latter Day Saints v. $U K$, the Church of Jesus Christ of Latter Day Saints, known also as the Mormon Church, sued the United Kingdom for granting dual exemptions to religious organizations. The United Kingdom allows a 100 percent exemption of property taxes for public places of worship and an 80 percent exemption for private ones. In this case, the Mormon temple in Lancashire, Preston, was only partially open to the public, thus it was not fully exempt from property taxes. The Mormon Church filed a complaint, citing 
Tax Exemptions for Religious Organizations: The United States, the European Union...| TOSUN

discrimination based on provisions in Article 14 and Article 9. The church explained that according to the nature of its worship, only church members were allowed to enter the temple. The Court decided that the lack of property tax exemption had not caused any difference in treatment between comparable groups because the tax law in question had been applied in the same way to all religious organizations, including private worship rooms, with similar results for all. Thus, the Court ruled that neither Article 14 nor Article 9 had been violated. Furthermore, it held that there was reasonable and objective justification for the difference in taxation and that all other religious groups in the country were subject to the same rule. Thus, no human rights had been violated (The Church of Jesus Christ of Latter-Day Saints v. UK 2014).

\subsection{Turkey}

Property taxes are important sources of revenue for municipalities in Turkey. Building and land owners pay these taxes annually. Pursuant to Paragraph g, Article 4, of the Property Tax Law,

The houses of worship which are for the performance of religious services and open to public and their outbuildings shall be permanently exempt from the real estate tax, provided that they are not leased.

The Property Tax Law further clarifies which properties are exempt: buildings belonging to associations that serve public benefit and that are not leased or otherwise subject to the corporate tax (Paragraph e, Article 4); buildings belonging to tax-exempt foundations that follow the law regarding such foundations (Paragraph m, Article 4); and lands belonging to associations that offer public benefit and that are not owned by enterprises subject to the corporate tax (Paragraph c, Article 14). Notably, lands and parcels belonging to foundations that are granted tax exemption are not exempt from property tax.

Granting property tax exemption only to houses of worship creates problems for religious organizations that are not considered as such. In 2016, in Izzettin Dogan and Others v. Turkey, the applicants argued that the Presidency of Religious Affairs limited its governance to houses of worship of the Sunni sect and excluded djemevis, which are houses of worship in the Alewi sect, thus prohibiting property tax exemptions for djemevis. The European Court of Human Rights found Turkey to be in violation of Article 9 and Article 14 of the ECHR. Initiatives were established to designate djemevis as houses of worship in Turkey (Izzettin Dogan \& Others v. Turkey, 2016). 


\subsection{Comparing Property Tax Policy in Turkey with Policies of the United States and the European Union}

Comparing property tax exemptions can be difficult, because the concepts of property differ across each country. In terms of religious organizations, the US, Turkey, and the EU grant large-scale exemptions for property taxes that usually require buildings to be open to the general public, offer public benefit, and not be used for commercial purposes. This exemption has been criticized in the US, as in the case of Walz v. Tax Commission of the City of New York (1970), for forcing people who do not subscribe to a religion to subsidize its houses of worship. In Turkey, lands and parcels belonging to religious foundations that are granted tax exemption are not given property tax exemption.

\section{ESTATE, INHERITANCE, AND GIFT TAXES IN THE UNITED STATES, THE EUROPEAN UNION, AND TURKEY}

Estates, inheritances, and monetary gifts often are taxed to prevent the accumulation of wealth and to correct income distribution. Opponents of this tax argue that it creates a disincentive for capital accumulation. Usually, inheritances and donations to charities are exempt from taxation because these organizations offer services that benefit society (Johnson, Eller, 1998). Although inheritance and estate taxes have been around much longer than gift taxes, the latter has become more prominent as individuals have learned to avoid posthumous taxes by giving away their fortunes while still alive.

These taxes vary around the world. For example, inheritance tax is an acquisitions-based tax that is applied to the beneficiary at different rates, depending on the degree of consanguinity. Estate tax focuses on what the decedent owned at the time of death. Both taxes involve inheritance, but have different applications. Each country's policy varies, depending on whether the donor or gift recipient pays the tax. Unrequited donations and inheritances are generally taxed if they exceed a certain amount, though there are many exceptions.

\subsection{United States}

The US is one of many countries that collects taxes upon transfer of ownership. Its federal government has three different methods for taxation of wealth transfer. The first is the estate tax, which is collected based on the net value of the assets of the deceased that have been transferred due to death. The second is the gift tax, which is collected from the donations made to other persons when the grantor was alive. The third is the generation-skipping tax, which is imposed when grandparents transfer their assets to their grandchildren without leaving them to their children (Greene, 2009). 
Tax Exemptions for Religious Organizations: The United States, the European Union...| TOSUN

The federal government agrees to deduct transfers to qualified charitable institutions to reach the taxable estate (tax base). This tax is not imposed frequently, because the amount of federal estate tax exemption is quite high, at $\$ 11,180,000$ US dollars for 2018 (Garber, 2018a).

In the US, the gift tax is generally collected at the federal level (in Connecticut, it is imposed at the state level), with rates of up to $12 \%$. Exemptions apply for donations made while someone is alive. As of 2019, donations made once a year and multiple donations made to the same person in one calendar year are subject to the gift tax unless they exceed the annual gift tax exemption limit of $\$ 15,000$ US dollars (Garber, 2019).

Wealth that has been transferred due to death is taxed separately in the states. Some states collect both estate and inheritance taxes. Since 2016, six states (Iowa, Kentucky, Maryland, Nebraska, New Jersey, and Pennsylvania) have collected inheritance taxes. Maryland and New Jersey also collect estate and inheritance taxes (Garber, 2018b).

The Internal Revenue Service exempts many donations (e.g., bequests to houses of worship) from estate and gift taxes (Gale, Slemrod, 2001). According to Martin (2017), such donations are acts of worship and thus not taxable, because the US Constitution guarantees that the state will not interfere with worship.

\subsection{European Union}

The EU has no standard regulation on inheritance and gift taxes. In EU countries, there are more than 15 different practices for handling these taxes. Double taxation may arise because of different applications by member states, and tax rates may also vary between them (Soniaeveldt, Zuiderwijk, 1995).

According to case law from the European Court of Human Rights, excessive taxation violates Article 9 of the ECHR if it prevents normal functioning of religious communities. For example, in 2011, France demanded a penal supplementary tax from the Jehovah's Witnesses Christian denomination on the grounds that it was a religious sect, and thus its donations did not qualify for the same exemptions that applied to gifts and legacies. The Court found this penal supplementary tax to be severe enough to bankrupt the institution and ruled that it infringed on the organization's freedom of thought, conscience, and religion (Ass'n of Jehovah Witness v. France 2011; Yalti, 2013). 


\subsection{Turkey}

In Turkey, the inheritance and gift tax is a dual, progressive tax, meaning that its rate changes depending on who receives the bequest and its amount (the higher the amount, the higher the tax rate). In accordance with Article 3-b of the Inheritance and Gift Tax Law, exemptions include

organizations belonging to legal entities that are open to the public and established for $[\ldots]$ purposes such as science, research, culture, art, health, education, religion, charity, development, [or] sport.

In accordance with Article 4-k, assets allocated to tax-exempt foundations for or after their establishment are exempt from the inheritance and gift tax.

4.4 Comparing Inheritance and Gift Tax Policy in Turkey with Policies in the United States and the European Union

Donations to houses of worship are exempt from the gift tax in the US. Other nonprofit religious organizations must be deemed a charitable institution by the Internal Revenue Service to be exempt from estate and gift taxes. Some countries in the EU tax these donations. However, the European Court of Human Rights ruled that excessive taxation impedes the freedom of conscience and religion. Turkey grants exemptions to houses of worship and other nonprofits via its Inheritance and Gift Tax Law. In Turkey, the fact that a nonprofit religious organization is not subject to this tax does not necessarily grant it status as a qualified charitable institution, as it does in the US. Exemptions from taxes on inheritances and bequests are granted only if everyone benefits from the organization's services, a determination that is made by the tax administration.

There is a fundamental difference in inheritance and gift taxation between the US and Turkey: In Turkey, the beneficiary pays the tax, but in the US, the donor pays it. Specifically, a charity in the US has no liability related to the donations or bequests it receives. In Turkey, a nonexempt religious association or foundation that is not open to the public must pay the inheritance and gift tax.

\section{VALUE ADDED TAX AND SALES TAX IN THE UNITED STATES, THE EUROPEAN UNION, AND TURKEY}

Although value added tax (VAT) and sales tax are both consumption taxes, VATs include general, indirect, and domestic consumption taxes on products at each stage of the supply chain, from production to sale, while sales tax is a consumption tax imposed only on the final retail sale. VATs and sales taxes apply to most commercial 
activities. For religious organizations, this can mean taxing sales of religious publications, or products such as souvenirs. Generally, these taxes do not constitute an obstacle to the fulfillment of religious obligations. However, organizations have challenged the validity of a VAT on the cost of constructing or repairing houses of worship.

\subsection{United States}

Unlike Turkey and EU countries, the US imposes sales tax but no VAT. Each state has its own sales tax and sales tax exemption laws for houses of worship. More than 10,000 sales tax rates are imposed across all states (Zelinsky, 2017). Some states, such as Connecticut and Alabama, offer sales tax exemptions for materials that will be used to construct houses of worship (Pinho, Rappa, 2016). In the 1989 case of Texas Monthly Inc. v. Bullock and the 1990 case of Jimmy Swaggart Ministries v. Board of Equalization of California, the Supreme Court decided that the sale of religious publications is profit-oriented and thus subject to general sales tax without violating the constitutionally protected freedom of worship (Martin, 2017).

\subsection{European Union}

As countries in the EU have attempted to align the various, country-specific VATs, the European Commission has initiated several investigations into these tax policies. For example, in December 2005, it requested that Spain amend its VAT policy for goods sold to the Catholic Church, noting that its exemption practice violated EU policy (Curtit, Fornerod 2015). In Denmark, nonprofit sector organizations (including religious institutions) receive a comprehensive exemption, but in 2008, the European Commission warned that these exemptions exceeded permissible levels and formally requested that Denmark change its laws (Curtit, Fornerod 2015). Except for the United Kingdom, most EU countries do not exempt construction or repair costs from taxation, although it has been periodically discussed (Seely, 2013).

\subsection{Turkey}

Turkey has attempted to align its VAT system with that of the EU. Article 13/k of the Value Added Tax Act exempts deliveries and services of those who donate to the construction of schools, health facilities, and houses of worship, including institutions that provide religious education under the supervision of the Department of Religious Affairs. However, there is no VAT exemption for commercial activities, such as selling religious publications or souvenirs, or for goods and services delivered by nonprofit organizations. 


\subsection{Comparing Value Added Tax Policy in Turkey with Policies in the United States and the European Union}

The US differs from Turkey and the EU in its taxes on consumption. The US collects sales tax from consumers at the final stage of consumption. The EU and Turkey, however, use a VAT system, which collects taxes at each stage of production. The US, the EU, and Turkey impose these taxes on revenue from the sale of religious publications and souvenirs, although there is no uniform application. Individual US states may grant partial exceptions or exemptions. The European Commission has examined this issue in recent years and issued warnings to countries whose VAT policies violate EU law. In 2018, Turkey released a comprehensive VAT exception for the building of houses of worship. Except for the United Kingdom, no country in the EU has this kind of exemption, though there are recommendations and discussions on the subject.

\section{CONCLUSION}

Taxation is a sensitive matter in diverse countries like the US, those in the EU, and Turkey, where people from different religions and sects live together at increasing rates. All these regions grant significant privileges to houses of worship and nonprofit religious organizations. However, tax regulations must comply with laws that protect freedom of thought, conscience, and religion, which can make taxation policies for houses of worship and religious organizations both complicated and unique. This study's findings revealed differences in religious-based tax policies between the US and the EU, compared with those of Turkey.

Turkey is geographically close to the EU. In its application to join the EU, Turkey implemented policies that aligned with those of EU countries and the US. For example, Turkey follows the US in not imposing a church tax like that of the EU.

The US has more extensive exemption privileges compared to EU member states or Turkey. However, those exemptions are subject to much more stringent rules than anywhere else, and tax-exempt organizations in the US can easily lose their status.

EU countries and Turkey are more cautious than the US in allowing income tax and corporate tax deductions for donations, even those made to tax-exempt organizations, which receive limited reductions. However, as mentioned previously, although the US grants full exemptions, it stipulates conditions that are not imposed in the EU or Turkey.

The definition of a house of worship is much narrower in Turkey than in the US or the EU. Turkey grants tax exemptions only to houses of worship of major religions 
Tax Exemptions for Religious Organizations: The United States, the European Union...| TOSUN

(e.g., mosques, churches, and synagogues). However, in line with recent decisions by the European Court of Human Rights, Turkey will likely expand its definition.

Property tax exemptions were also similar across the countries studied in that properties had to be open to the public and not used commercially. In Turkey, however, lands and parcels belonging to religious foundations are not exempt from property tax.

Estate, inheritance, and gift taxes, as well as related policies for religious organizations, differ across countries. The study found that Turkey had the most extensive exemptions for inheritances and gifts based on its Inheritance and Gift Tax Act.

Finally, Turkey and EU countries differed from the US in terms of consumption taxes, such as VATs and sales taxes. The former countries have been aligning these policies via court decisions and other statutes, and these taxes have not been found to constitute an obstacle to the fulfillment of religious obligations.

No consensus has been reached regarding tax exemptions for houses of worship and other religious organizations. The persistent differences in tax policies across the US, the EU, and Turkey are likely to have historical, cultural, and political effects. To avoid problems, national and international laws should be enacted to eliminate this conflict.

In this study, the tax policies of the US, the EU, and Turkey were examined in the context of religious institutions. It should be noted that these laws may vary between states in the US and between countries in the EU, and that this study only addressed the general aspects of both systems. Future studies should analyze the differences between state policies in the US and national policies in the EU.

\section{REFERENCES}

Anheier H.K,, W. Seibel (1993), Defining the Nonprofit Sector: Germany. Working Papers of the Johns Hopkins Comparative Nonprofit Sector Project, no. 6. Baltimore: The Johns Hopkins Institute for Policy Studies.

Archambault E. (1997), The Nonprofit sector in France. Johns Hopkins Nonprofit Sector Series 3. New York: Manchester University Press.

Association of Jehovah's Witness v. France (2011), App. no. 8916/05. European Court of Human Rights.

Barbetta G.P. (1999), "Foundations in Italy”, in H. K. Anheier \& S. Toepler (ed.), Private Funds, Public Purpose Philanthropic Foundations in International Perspectives, New York: Springer Science-Business Media, 203 
TOSUN | Dini Organizasyonlar İçin Vergi Muafiyetleri:Amerika Birleşik Devletleri, Avrupa Birliği...

Berghammer C, U. Zartler, D. Krivanek (2018), "Looking Beyond the Church Tax: Families and the Disaffiliation of Austrian Roman Catholics", Journal for the Scientific Study of Religion, 56, 514-535.

Brown H.H., Jr. J.J. Mahon (1959), "Church and State-Taxation of Religious OrganizationsBenefits Granted by Federal and State Governments", Villanova Law Review, 5, 255280.

Brunson S.D., D.J. Herzig (2017), “A Diachronic Approach to Bob Jones: Religious Tax Exemptions After Obergefell”, Indiana Law Journal, 92, 1175-1219.

Centre d'Étude et de Recherche sur la Philanthropie. (2015), An overview of philanthropy in Europe, http://fdnweb.org/ffdf/files/2014/09/philanthropy-in-europe-overview-2015report.pdf. Accessed 3 September 2018.

Council of Europe Research Divisions (2011), Overview of the Court's Case-Law on Freedom of Thought, Conscience and Religion.

https://www.echr.coe.int/Documents/Research_report_religion_ENG.pdf. Accessed 25 March 2018.

Crimm N.J., H.L. Winer (2013), "Tax Law Bans on Political Campaign Speech by Houses of Worship: Inappropriate Government Censorship and Intrusion on Religion”, Journal of Law, Religion, and State, 2, 101-136.

Curtit F, A. Fornerod (2015), "State Support for Religions: European Regulation”, in F. Messner (ed.), Public Funding of Religions in Europe, Farnham: Ashgate, 3-22.

European Commission (2014), Turkey 2014 Progress Report. https://ec.europa.eu/neighbourhoodenlargement/sites/near/files/pdf/key-documents/2014/20141008-turkey-progressreport_en.pdf. Accessed 25 December 2018.

European Fundraising Association (2018), Tax Incentives for Charitable Giving in Europe. https://efa-net.eu/wp-content/uploads/2018/12/EFA-Tax-Survey-Report-Dec-2018.pdf. Accessed 25 December 2018.

Faulhaber L.V. (2014), "Charitable Giving, Tax Expenditures, and Direct Spending in the United States and the European Union", Yale Journal of International Law, 39, 87-129.

Fisher L. (2002), "Statutory Exemptions for Religious Freedom”, Journal of Church and State, 44, 291-316.

Fricke M. (2016), "The case against income tax exemption for nonprofits", St. John's Law Review, 89, 1129-1284.

Gale W.G., J.B. Slemrod (2001), Rethinking the Estate and gift tax: Overview. NBER Working Paper, No. 8205. https://www.bus.umich.edu/otpr/WP2001-5paper.pdf. Accessed 25 December 2018.

Garber J. (2018a), Differences Between the Estate Tax and an Inheritance Tax. https://www.thebalance.com/differences-between-estate-and-inheritance-tax-3505472. Accessed 7 March 2019.

Garber J. (2018b), What is an Inheritance? https://www.thebalance.com/definition-of-inheritancetax-3505560. accessed 7 March 2019. 
Tax Exemptions for Religious Organizations: The United States, the European Union...| TOSUN

Garber J. (2019), The Federal Gift Tax and how you can Avoid Paying it. https://www.thebalance.com/gift-tax-exclusion-annual-exclusion-vs-lifetimeexemption-3505656. Accessed 7 March 2019.

Golden Writ of God v. Dept. of Rev. (1986), OTC 1897 SC S31518. Supreme Court of Oregon.

Greene P. (2009), Federal Estate and Gift Taxes, https://www.cbo.gov/sites/default/files/111thcongress-2009-2010/reports/12-18-estate_gifttax_brief.pdf. Accessed 7 March 2019.

Howard V.K. (1971), “Constitutional Law: Tax Exemption and Religious Freedom”, Marquette Law Review, 54, 386-390.

Iglesia Bautista El Salvador and José Aquilino Ortega Moratilla v. Spain. (1992), App. no. 17522/90. European Court of Human Rights.

Izzettin Dogan, Others v. Turkey (2016), App. no. 62649/10. European Court of Human Rights.

Johnson B.W., M.B. Eller (1998), "Federal Taxation of Inheritance and Wealth Transfers", in R.K. Miller, Jr. \& S.J. McNamee (ed.), Inheritance and wealth in America. https://www.irs.gov/pub/irs-soi/inhwlttr.pdf. Accessed 2 January 2019.

Martin M.J. (2017), "Should the Government be in the Business of Taxing Churches?", Regent University Law Review, 29, 309-336.

McCormack W.S. (2011), "Too Close to Home: Limiting the Organizations Subsidized by the Charitable Deduction to those in Economic Need", Florida Law Review, 63, 911.

Pinho R., J. Rappa (2016), Sales Tax Exemption for Building Materials used in State Construction Projects. Connecticut General Assembly Office of Legislative Research http://www.cga.ct.gov/2016/rpt/pdf/2016-R 0149.pdf. Accessed 3 September 2018.

Roemhildt M.C. (2003), "Religious Tax Exemption and the Charitable Scrutiny Test", Regent University Law Review, 15, 295-326.

Seely A. (2013), VAT and Churches. House of Commons Library. https://researchbriefings.files.parliament.uk/documents/SN01051/SN01051.pdf. Accessed 3 September 2018.

Shertreet S. (2007), "The Model of State and Church Relations and its Impact on the Protection of Freedom of Conscience and Religion: A Comparative Analysis and a Case Study of Israel”, in W. Brugger, \& M. Karayanni (ed.), Religion in the public sphere: A comparative analysis of German, Israeli, American and international law, New York: Springer, 87-162.

Soniaeveldt F., J. Zuiderwijk (1995), "Harmonization of Inheritance, Estate, and Gift Taxes Within the EU”, EC Tax Review, 4, 88-96.

The Church of Jesus Christ of Latter-Day Saints v. UK. (2014), App. no. 7552/09. European Court of Human Rights.

Vaughn J.E. (2004), "Reaping where they have not Sowed: Have American Churches Failed to Satisfy the Requirements for the Religious tax Exemption?", The Catholic Lawyer, 43, 29-159.

Walz v. Tax Commission of the City of New York. (1970), 397 U.S. 664. U.S. Supreme Court. Whitehead J.W. (1991), "Tax Exemption and Churches: A Historical and Constitutional Analysis", Cumberland Law Review, 22, 521-593. 
TOSUN | Dini Organizasyonlar İçin Vergi Muafiyetleri:Amerika Birleşik Devletleri, Avrupa Birliği...

Yaltı B. (2013), “İbadethane Bağışlarının Vergi Matrahından İndirimi: Vergide Eşitsizlik Örneği” Marmara Üniversitesi Hukuk Fakültesi Hukuk Araştirmalari Dergisi-Özel Sayi-Prof. Dr. Nur Centel'e Armağan, 19, 429-452. (Marmara University Faculty of Law, Legal Research Journal Special Issue in Honor of Prof. Nur Centel)

Zelinsky E. (2017), Taxing the Church: Religion, Exemptions, Entanglement and the Constitution. New York: Oxford University Press. 